\title{
Classe $^{1}$
}

The Class

\section{Michel Yakov Hubner**}

Colégio Iavne | São Paulo, Brasil

marcushubner@gmail.com

Gabi, sempre com comentários peculiares.

Ele nos mostra

As situações através de outros olhares.

Joseph, o zagueiro.

Na defesa

É o pioneiro.

Saul, o segurança de rodapé.

É baixinho,

Mas hilário de deixar o cabelo em pé.

Ariel, o riso em pessoa.

Tê-lo por perto

Sempre é uma boa.

Itai, dos pokémons é o treinador.

Sempre se esforça

Com muito fervor.

Julio, criador de dinossauros, como

Velociraptor e dimorfodonte.

Tem uma dúvida?

Ele é a fonte.

Ezra, o são-paulino

Com certeza

Ele conhece o hino.

Alberto, o que vai bem no estudo.

Dentro de sala

Ele nunca está mudo.

David do futebol.

\footnotetext{
${ }^{1}$ Publicado originalmente em Pirata, fantasma e Ninja: deixe que ele se finja, pela Scortecci Editora, em 2017.

** Poeta, músico e escritor, tem 13 anos e é aluno do Ensino Fundamental no Colégio Iavne (São Paulo).
} 
Você o encontrará jogando

De manhã até o pôr-do-sol.

Henri, o não peculiar.

Então escrevi isso

Porque ele não pode faltar.

Nissim, o bem acompanhado

Sempre há amigos

Que ficam ao seu lado.

Daniel, o jogador.

Acha que ele só joga futebol?

Não, ele também usa o computador.

Haim, a pessoa da organização

Ele tem

Qualquer informação

Eliane, a professora do momento

Ela ajuda,

Não importa em qual tempo.

Michael, o escritor de poemas.

Esforço e dedicação

São o seu emblema.

Recebido em: 22/02/2018.

Aprovado em: 17/03/2018. 